\title{
La società dei consumi è democratica?
}

\section{Victoria de Grazia}

Storicamente, 2 (2006).

ISSN: 1825-411X. Art. no. 65. DOI: 10.12977/stor538

18 maggio 2006

\section{Prof.ssa Victoria De Grazia}

(Columbia University, New York- Istituto Universitario Europeo, Fiesole)

La società dei consumi è democratica?

(conferenza)

[[figure]]figures/2006/De-Grazia_1/De-Grazia_1_2006_01.jpg[[/figure]] 